\title{
Altitudinal distribution and species richness of herbaceous plants in campos rupestres of the Southern Espinhaço Range, Minas Gerais, Brazil
}

\author{
Distribuição altitudinal e riqueza de espécies de plantas herbáceas em campos rupestres do sul da \\ Cadeia do Espinhaço, Minas Gerais, Brasil
}

\author{
Rafael Augusto Xavier Borges ${ }^{1,2}$, Marco Antônio Alves Carneiro ${ }^{1} \&$ Pedro Lage Viana $^{3}$
}

\begin{abstract}
The variation in the species richness of herbaceous plants along an altitudinal gradient was analyzed in the Serra do Ouro Branco and Serra do Ribeiro, in the townships of Ouro Branco and Ouro Preto, respectively. Plant similarity between both serras was also assessed. Twenty spots were sampled along a $440 \mathrm{~m}(1105 \mathrm{~m}$ to $1545 \mathrm{~m}$ ) altitudinal range; at each site, herbs were collected within ten $1 \mathrm{~m}^{2}$ plots, totaling $200 \mathrm{~m}^{2}$. We found 101 species distributed in 59 genera and 25 families. The richest plant families in Serra do Ouro Branco were Poaceae (22 spp.), Asteraceae (14 spp.) and Cyperaceae (10 spp.), while in Serra do Ribeiro, they were Poaceae (17 spp.), Cyperaceae (12 spp.) and Asteraceae (8 spp.). Variation between the number of species and altitude was not significant. The higher number of species in Serra do Ouro Branco may be due to different local environmental factors and to the occurrence of grazing and fires. The serras presented a high similarity value $(\mathrm{J}=0.44)$, but cluster and ordination analysis indicated the formation of two distinct groups, reflecting the importance of local factors to determine the floristic composition of neighboring areas of campos rupestres. Key words: biogeography, gradient, diversity, mountains, similarity.

\section{Resumo}

A variação da riqueza de plantas herbáceas ao longo do gradiente altitudinal foi estudada em campos rupestres das Serras do Ouro Branco e do Ribeiro, localizadas respectivamente nos municípios de Ouro Branco e Ouro Preto. A similaridade entre a flora das serras também foi verificada. Foram amostrados 20 pontos num gradiente altitudinal de $440 \mathrm{~m}$ (1.105 m a $1.545 \mathrm{~m})$; em cada ponto, as ervas foram coletadas em parcelas de $1 \mathrm{~m}^{2}$, totalizando $200 \mathrm{~m}^{2}$. Foram encontradas 101 espécies em 59 gêneros e 25 famílias. Na Serra do Ouro Branco, as famílias com maior número de espécies foram Poaceae (22 spp.), Asteraceae (14 spp.) e Cyperaceae (10 spp.), enquanto na Serra do Ribeiro foram Poaceae (17 spp.), Cyperaceae (12 spp.) e Asteraceae (8 spp.). Não houve variação significativa da riqueza de espécies com a altitude e a Serra do Ouro Branco apresentou um maior número de espécies. As serras apresentaram elevada similaridade entre si $(\mathrm{J}=0,44)$, porém houve a formação de dois grupos distintos nas análises de agrupamento e ordenação, indicando que a riqueza de espécies em áreas relativamente próximas de campo rupestre podem estar sob influência de fatores locais predominantes.
\end{abstract}

Palavras-chave: biogeografia, gradiente, diversidade, montanhas, similaridade.

\section{Introduction}

Although Brazilian mountain ecosystems are of great ecological and economic importance, they are threatened by human activities and their biology is poorly known (Martinelli 2007). Studies on tropical mountain ranges are important to understand the processes and mechanisms that influence biodiversity and organism responses to environmental changes, as global warming (Gottfried et al. 1999; Lomolino 2001; Beckage et al. 2008).

\footnotetext{
'Universidade Federal de Ouro Preto (UFOP), Instituto de Ciências Exatas e Biológicas, DEBIO, Lab. Entomologia Ecológica, 35400-000, Ouro Preto, MG, Brasil. ${ }^{2}$ Centro Nacional de Conservação da Flora-PROBIO II, Instituto de Pesquisas Jardim Botânico do Rio de Janeiro (JBRJ), R. Pacheco Leão 915, 22460-030, Rio de Janeiro, RJ, Brasil. Autor para correspondência: rafaelborges@jbrj.gov.br

${ }^{3}$ Universidade Federal de Minas Gerais (UFMG), Instituto de Ciências Biológicas (ICB), Dep. Botânica, 30123-970, Belo Horizonte, MG, Brasil.
} 
Variations in species richness along altitudinal gradients are relatively well studied (Hodkinson 2005). In short, two plant species distribution patterns were described for different organisms and biogeographical regions (Lomolino et al. 2006). The first one maintains that the number of species decreases as altitude increases (Rosenzweig 1995). This negative linear relationship was reported for different organisms, as birds (Terborgh 1977), herbivore insects (Fernandes \& Price 1988; McCoy 1990; Carneiro et al. 1995) and plants (Givnish 1999; Jones et al. 2003). The second one holds that the number of species diminishes as we get closer to the extremes of the altitudinal gradient, and defines a maximum value of species richness at intermediate altitudes (Gentry \& Dodson 1987; Rahbek 1997; Colwell \& Lewis 2000; Lomolino 2001; Grytnes 2003). It was described for different groups of plant species (Tryon 1989; Grytnes 2003; Bachman et al. 2004; Krömer et al. 2005), herbivore insects (McCoy 1990), birds (Herzog et al. 2005) and mammals (Nor 2001).

Campos rupestres are found in the states of Minas Gerais, Bahia and Goiás. They are usually constituted by mosaics of plant communities, formed by a herbaceous stratum followed by perennial and sclerophyllous bushes and subshrubs occurring at altitudes between 900 and $2070 \mathrm{~m}$, on great extensions of quartzitic outcrops with shallow, compact litholic soils (Giulietti \& Pirani 1988; Romero 2002). The herbaceous stratum is mainly formed by species of the families Poaceae, Cyperaceae, Eriocaulaceae and Xyridaceae. The bush stratum comprises a high number of species of Asteraceae, Melastomataceae, Lamiaceae, and Velloziaceae (Giulietti \& Pirani 1988).

In the southern Espinhaço Range, the Quadrilátero Ferrífero (Iron quadrangle) stands out by its rich deposits of mineable resources and remarkable biological diversity (Drummond et al. 2005). The region is distinguished by its high diversity of habitats, which may be related to edaphic peculiarities, to the characteristic mountain relief of the region and to the fact that it is located in a transition area between the Atlantic Forest and cerrado biomes (Council \& Murta 2007). Among its different phytophysiognomies, we can mention forest (e.g. seasonal forests, gallery forests, cloudy forests), savanna (cerrado sensu stricto) and grassland (campos rupestres on quartzite, campos rupestres on canga and campos limpos) formations (Viana \& Lombardi 2007).
The present work surveyed herbaceous plants in two serras located in the southern Espinhaço Range and verified if species richness diminishes with altitude. The influence of the environmental heterogeneity on the species composition of each serra was also assessed by analyzing the floristic similarity of the sampled places.

\section{Material and Methods}

This work was carried out in Serra do Ouro Branco (SOB) and Serra do Ribeiro (SR), located in the townships of Ouro Branco and Ouro Preto (Fig. $1)$, respectively. The SOB stands out as the most significant element of the southern border of the Quadrilátero Ferrifero. The altitude of its circa 65 ha varies from 1,000 to $1,573 \mathrm{~m}$ (Alkmim 1987). Located approximately $10 \mathrm{~km}$ to the North of the SOB, with altitudes varying between 1,270 and 1,550 $\mathrm{m}$, the SR comprises a set of two smaller formations. Climate is mesothermic - Cwb (Köppen 1948), with mild, rainy summers and dry, cold winters. Mean annual temperatures vary between $17^{\circ} \mathrm{C}$ and $20^{\circ} \mathrm{C}$ and the annual rainfall records are approximately 1,500 mm (Giulietti \& Pirani 1988). In the campos rupestres of both serras, the sampling places are characterized as quartzitic grasslands with or without subshrubs (Rizzini 1979), usually next to rocky outcrops, sometimes with evidence of grazing and fires.

Field expeditions were carried out between March and July 2004. Ten collection points arbitrarily defined, in an attempt to encompass the different types of habitats along the altitudinal gradient of each serra, were sampled; geographical coordinates and spot heights (Tab. 1) were determined using an Etrex Venture (Garmin $\left.{ }^{\circledR}\right)$ GPS . Sampling was performed in ten $1 \mathrm{~m}^{2}$ plots systematically distributed, at a distance of $5 \mathrm{~m}$ from each other along a $50 \mathrm{~m}$ imaginary line (Pivello et al. 1999), so that $10 \mathrm{~m}^{2}$ were sampled at each altitudinal point, totaling $200 \mathrm{~m}^{2}$. Plants were identified by comparison with specimens kept at the OUPR and BHCB herbaria (acronyms according to Holmgren et al. 1990) and with the help of specialists. Only the angiosperms composing the herbaceous stratum were sampled. Fertile samples were deposited at the OUPR herbarium. Botanical families are circumscribed according to the Angiosperm Phylogeny Group - APG II (APG 2003).

Analyses of covariance were performed to determine if plant species richness diminishes with 


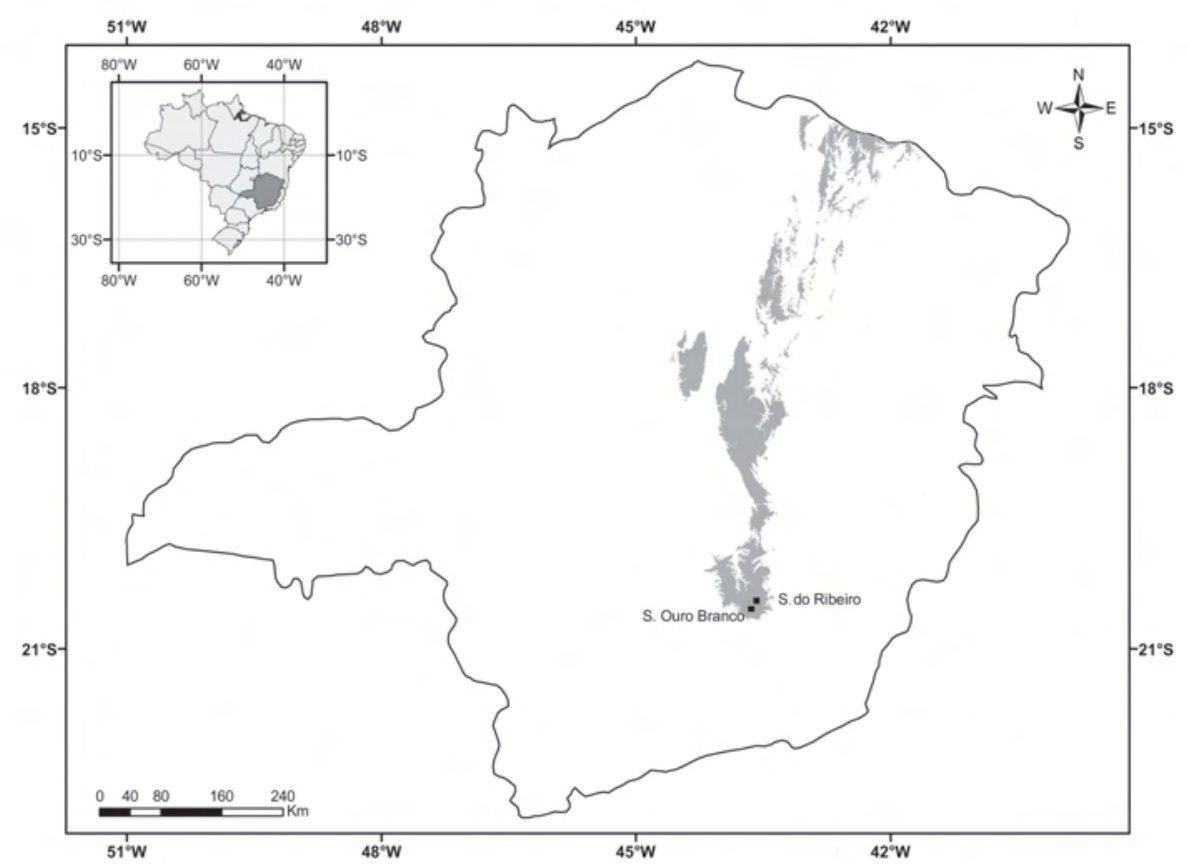

Figure 1 - Localization of the study areas in the southern Espinhaço Range, Minas Gerais, Brazil.

altitude (Crawley 2002). On our model, plant richness was the response variable and altitude (covariable) and the serras (categorical variable) were the explanatory variables. The analyses were performed with the statistical package $\mathrm{R}$ version 2.5.1 ( $\mathrm{R}$ Development, Core Team 2005), using the 'glm' procedure, and Poisson errors were calculated through chi-square tests $\left(\chi^{2}\right)$. Residual analyses were carried out to check error distribution and adjust the model (Crawley 2002).

We used the Jaccard index to measure similarity between the sampling points (McCune \& Grace 2002) and the relationships between them were characterized by cluster and ordination analyses based on the method of unweighted means (UPGMA), using the FITOPAC software (Shepherd 1996), and on a multidimensional scale analysis (MDS) carried out with XLSTAT data analysis and statistical solution for Microsoft ${ }^{\circledR}$ Excel 2007.

\section{Results}

One hundred and one species distributed in 59 genera and 25 families were collected in the two studied serras (Tab. 2). The families with the highest number of species were Poaceae (25), Asteraceae (14), Cyperaceae (13) and Polygalaceae (9). Out of this total, 86 species grow in the SOB, 41 of which are exclusive to it, and 61 species occur in the SR, 16 of which are exclusive to it (Tab. 2). In the SOB, the families with the greatest number of species were Poaceae (22), Asteraceae (14) and Cyperaceae (10), while in the SR, they were Poaceae (17), Cyperaceae (12) and Asteraceae (8).

The species growing in the widest altitudinal range, since they found practically along the whole gradient of both places, were Inulopsis scaposa (Asteraceae) and Echinolaena inflexa (Poaceae). The most frequent species in both serras were: Inulopsis scaposa and Lessingianthus linearifolius (Asteraceae); Bulbostylis paradoxa (Cyperaceae); Apochloa poliophylla, Echinolaena inflexa, Mesosetum loliifome and Paspalum hyalinum (Poaceae); Polygala paniculata and $P$. longicaulis (Polygalaceae). A single sampling point presented 33 species and no exotic species were collected in the study (Tab. 2).

Although there was no significant variation in species richness with altitude for herbaceous plants $\left(\chi^{2}=2.170 ; p=0.141, n=20\right)$, a higher number of species was found in the SOB $\left(\chi^{2}=\right.$ 16.515; $\mathrm{p}<0.0001 ; \mathrm{n}=20$ ) (Fig. 2). When each of the four richest plant families were analyzed separately, the same pattern was found between the number of species and the explanatory 
Table 1 - Localization, spot height and description of the collection points in the Serra do Ouro Branco (OB) and in the Serra do Ribeiro (SR).

\begin{tabular}{|c|c|c|c|}
\hline Places & Geographic Coordenates & Description & Altitude (m) \\
\hline OB1 & $20^{\circ} 30^{\prime} 21,8^{\prime \prime} \mathrm{S} ; 43^{\circ} 38^{\prime} 35^{\prime \prime} \mathrm{W}$ & Grassland with a dense herbaceous stratum and small outcrops. & 1314 \\
\hline OB2 & $20^{\circ} 30^{\prime} 6,4^{\prime} \mathrm{S} ; 43^{\circ} 38^{\prime} 10,3^{\prime \prime} \mathrm{W}$ & Grassland with rare bushes close to the serra watershed. & 1232 \\
\hline OB3 & $20^{\circ} 30^{\prime} 34,5 ’ \mathrm{~S} ; 43^{\circ} 37^{\prime} 54,4 ’ \mathrm{~W}$ & Grassland with a dense herbaceous stratum, close an outcrop with velozias. & 1190 \\
\hline OB4 & $20^{\circ} 30^{\prime} 28,6 ” S ; 43^{\circ} 37^{\prime} 32,8^{\prime \prime} \mathrm{W}$ & Grassland with bushes and subshrubs. & 1236 \\
\hline OB5 & $20^{\circ} 30^{\prime} 17,6 ’ \mathrm{~S} ; 43^{\circ} 39^{\prime} 26,6^{\prime \prime} \mathrm{W}$ & Grassland with small outcrops, few bushes and small trees. & 1318 \\
\hline OB6 & $20^{\circ} 30^{\prime} 1,1^{\prime \prime} \mathrm{S} ; 43^{\circ} 41^{\prime} 3,5^{\prime \prime} \mathrm{W}$ & Grassland close to a riparian forest, with signs of fires and cattle grazing. & 1363 \\
\hline OB7 & $20^{\circ} 29^{\prime} 12,9^{\prime \prime} \mathrm{S} ; 43^{\circ} 42^{\prime} 36,7^{\prime \prime} \mathrm{W}$ & Grassland with outcrops and a large population of velozias. & 1544 \\
\hline OB8 & $20^{\circ} 29^{\prime} 4,2^{\prime \prime} \mathrm{S} ; 43^{\circ} 42^{\prime} 22,7^{\prime \prime} \mathrm{W}$ & Grassland close to the serra watershed with signs of cattle grazing. & 1477 \\
\hline OB9 & $20^{\circ} 30^{\prime} 18,9^{\prime \prime} \mathrm{S} ; 43^{\circ} 36 ’ 28,6^{\prime \prime} \mathrm{W}$ & Grassland close to a riparian forest with signs of cattle grazing. & 1105 \\
\hline OB1 & $20^{\circ} 30^{\prime} 29,5^{\prime \prime} \mathrm{S} ; 43^{\circ} 37^{\prime} 5,5^{\prime \prime} \mathrm{W}$ & Grassland with a large population of velozias. & 1254 \\
\hline SR1 & $20^{\circ} 27^{\prime} 27,4^{\prime \prime} \mathrm{S} ; 43^{\circ} 36^{\prime} 9^{\prime \prime} \mathrm{W}$ & Grassland with waterlogged areas on clayey soil. & 1517 \\
\hline $\mathrm{SR} 2$ & $20^{\circ} 27^{\prime} 19,2 ” S ; 43^{\circ} 35^{\prime} 7,3^{\prime \prime} \mathrm{W}$ & Slope grassland with outcrops and waterlogged areas on clayey soil. & 1367 \\
\hline SR3 & $20^{\circ} 27^{\prime} 41,6 ” S ; 43^{\circ} 35^{\prime} 4^{\prime \prime} \mathrm{W}$ & Grassland with few bushes close to a large outcrop and a watershed with riparian forest. & 1314 \\
\hline SR4 & $20^{\circ} 29^{\prime} 1,9^{\prime \prime} \mathrm{S} ; 43^{\circ} 35^{\prime} 1,5^{\prime \prime} \mathrm{W}$ & Grassland surrounded by small outcrops and velozias. & 1381 \\
\hline SR5 & $20^{\circ} 28^{\prime} 19,8^{\prime \prime} \mathrm{S} ; 43^{\circ} 34^{\prime} 51,9^{\prime \prime} \mathrm{W}$ & Grassland with bushes, close a small outcrop. & 1318 \\
\hline SR6 & $20^{\circ} 28^{\prime} 20,8^{\prime \prime} \mathrm{S} ; 43^{\circ} 35^{\prime} 15^{\prime \prime} \mathrm{W}$ & Grassland with bushes close to the serra watershed with great erosion. & 1294 \\
\hline SR7 & $20^{\circ} 29^{\prime} 4,3^{\prime \prime} \mathrm{S} ; 43^{\circ} 34^{\prime} 45,8^{\prime \prime} \mathrm{W}$ & Grassland with small outcrops close to a creek. Moist and loose soil. & 1458 \\
\hline SR8 & $20^{\circ} 28^{\prime} 50,6^{\prime \prime} \mathrm{S} ; 43^{\circ} 34^{\prime} 54,1^{\prime \prime} \mathrm{W}$ & Grassland with a dense herbaceous stratum, close to an outcrop and small temporary lakes. & 1545 \\
\hline SR9 & $20^{\circ} 29 ’ 3,4^{\prime \prime} \mathrm{S} ; 43^{\circ} 34^{\prime} 5,8^{\prime \prime} \mathrm{W}$ & Grassland with a dense herbaceous stratum and moist soil, between a large outcrop and a creek. & 1438 \\
\hline SR10 & $20^{\circ} 29^{\prime} 7,2 ” S ; 43^{\circ} 34^{\prime} 25,4^{\prime \prime} \mathrm{W}$ & Grassland with small outcrops and a large population of velozias. & 1472 \\
\hline
\end{tabular}


Table 2 - Presence (+) and absence (-) of species of herbaceous plants along the altitudinal gradient in the serras do Ouro Branco and do Ribeiro, located in the Espinhaço Range, Minas Gerais, Brazil. Voucher material is represented by the collection number of R.A.X. Borges (B).

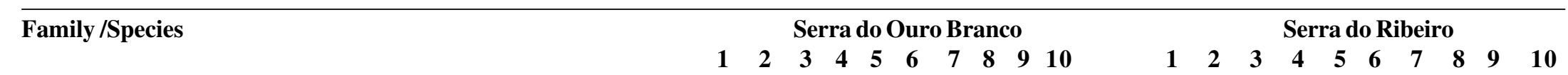

\section{Amaranthaceae}

Gomphrena scapigera Mart. (B 96)

\section{Apiaceae}

Eryngium pandanifolium Cham \& Schltdl. (B 58)

\section{Aristolochiaceae}

Aristolochia smilacina Duch. (B 15)

\section{Apocynaceae}

Barjonia erecta (Vell.) Schw. (B 32)

\section{Asteraceae}

Baccharis aphylla DC. (B 45)

Calea pilosa Baker (B 37)

Chromolaena decumbens (Gardner) R.M. King \& H. Rob. (B 10)

Heterocondylus amphidictyus (DC.) R.M. King \& H. Rob. (B 54)

Inulopsis scaposa (DC.) O. Hoffm. (B 1)

Lessingianthus linearifolius (Less.) H. Rob. (B 21)

Mikania microphylla Sch. Bip. ex Baker (B 46)

Porophyllum lineare DC. (B 31)

Richterago radiata (Vell.) Roque (B 40)

Stevia lundiana DC. (B 39)

Lessingianthus psilophyllus (Gardner) H. Rob. (B 71)

Stenocephallum megapotamicum (Spreng.) Sch. Bip. (B 35)

Eupatoriae sp1 (B 108)

Vernoniae sp1 (B 88)

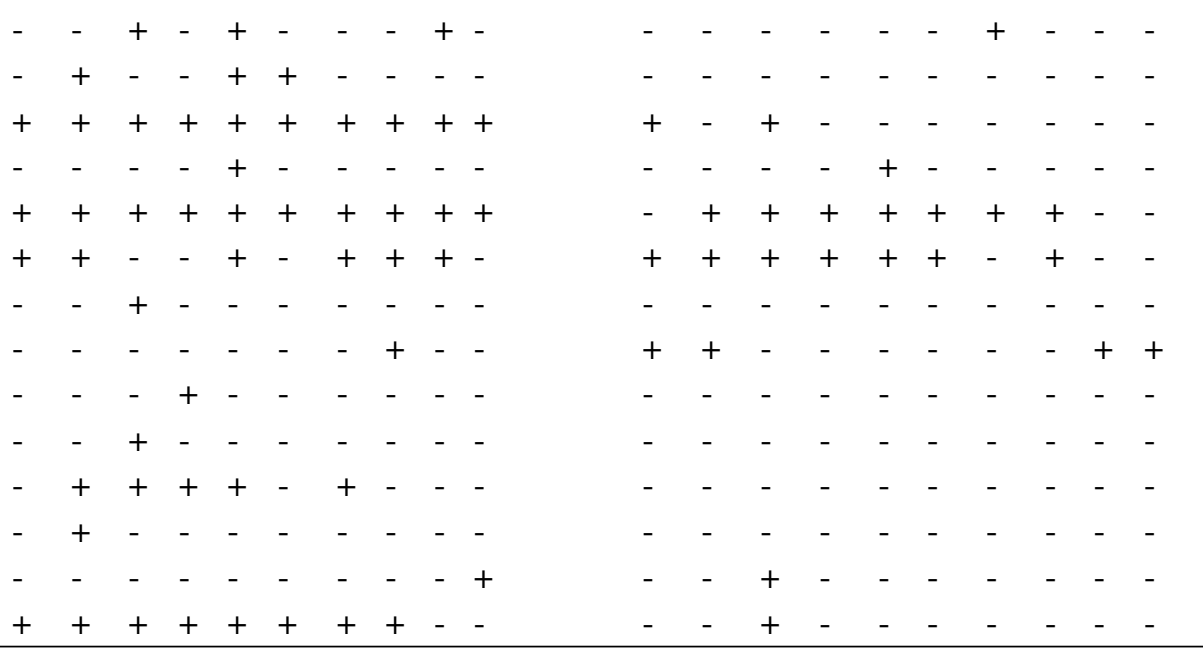




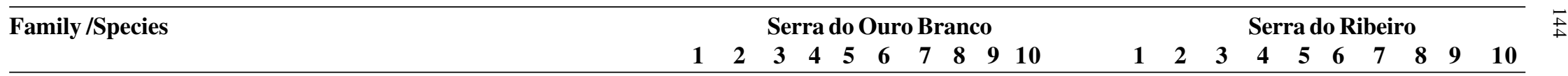

\section{Burmanniaceae}

Burmannia bicolor Mart. (B 131)

\section{Convolvulaceae}

Ipomoea procumbens Mart. ex Choisy (B 69)

Evolvulus aurigenius Mart. (B 70)

\section{Cyperaceae}

Bulbostylis jacobinae (Spreng) Lindm (B 114)

Bulbostylis junciformis (Humb.Borpl. \& Kunth.) C.B. Clarke (B 111)

Bulbostylis capillaris (L.) C.B. Clarke (B 90)

Bulbostylis paradoxa (Spreng.) Lindm. (B 3)

Bulbostylis scabra (Persl.) C.B.Clarke (B 7)

Lagenocarpus rigidus (Kunth) C.B. Clarke (B 130)

Lagenocarpus tenuifolius (Kunth) C.B. Clarke (B 62)

Rhynchospora consanguinea Boeck. (B 120)

Rhynchospora lapensis C.B. Clarke (B 118)

Rhynchospora pilosa (Kunth) Boeck (B 121)

Rhynchospora setigera (Kunth) Boeck. (B 123)

Scleria virgata Stench. (B 52)

Scleria cuyabensis Pilg. (B 53)

\section{Droseraceae}

Drosera montana A. St-Hil. (B 84)

\section{Eriocaulaceae}

Paepalanthus freyreissii (Thumb) Koern. (B 117)

Paepalanthus pubescens var. chapadensis (Koern.) Ruhl. (B 119)

Paepalanthus sphaerocephalus Ruhl. (B 97)

Syngonanthus caulescens (Poir.) Ruhl. (B 132)
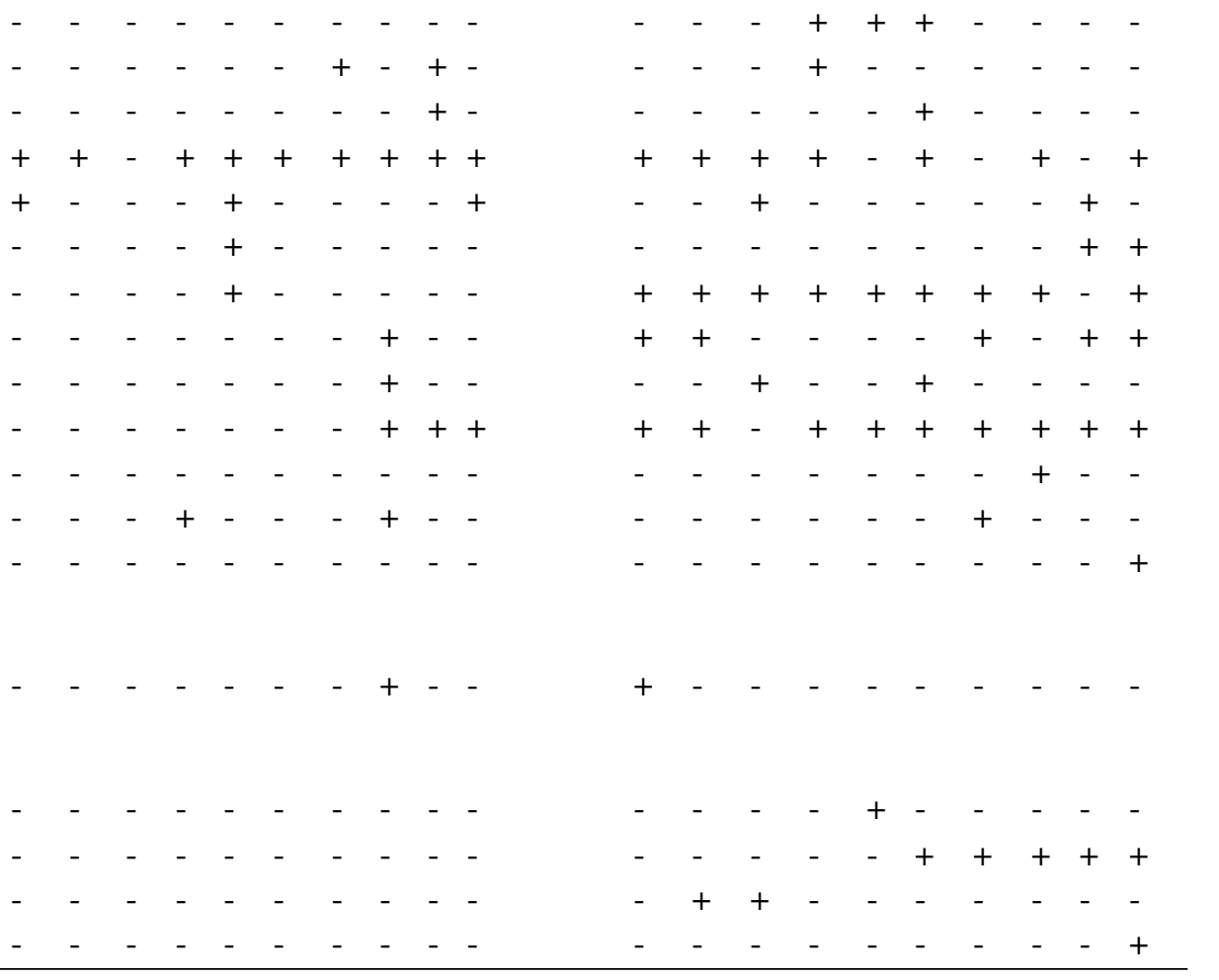


\section{Family/Species}

\section{Serra do Ouro Branco}

$\begin{array}{llllllllll}1 & 2 & 3 & 4 & 5 & 6 & 7 & 8 & 9 & 10\end{array}$

Serra do Ribeiro

$\begin{array}{llllllllll}1 & 2 & 3 & 4 & 5 & 6 & 7 & 8 & 9 & 10\end{array}$

\section{Poaceae}

Apochloa euprepes (Renvoize) Zuloaga \& Morrone (B 94)

Apochloa poliophylla Renvoize \& Zuloaga (Zuloaga \& Morrone) (B 42)

Aristida recurvata Kunth (B 20)

Aristida torta (Ness) Kunth (B 47)

Axonopus brasiliensis (Spreng.) Kuhlm. (B 17)

Axonopus canescens Ness ex Trin. (B 61)

Axonopus chrysoblepharis (Lag.) Chase (B 13)

Axonopus fastigiatus (Ness) Khulm. (B 25)

Axonopus pressus (Ness ex Steud.) Parodi (B 79)

Echinolaena inflexa (Poir.) Chase (B 4)

Mesosetum loliiforme (Hochst. ex Steud.) Chase (B 5)

Paspalum hyalinum Ness ex Trin. (B 2)

Paspalum polyphyllum Ness ex Trin. (B 18)

Schizachyrium sanguineum (Retz.) Alston (B 100)

Schizachyrium tenerum Ness. (B 67)

Sporobolus metallicolus Longhi-Wagner \& Boechat (B 34)

Steinchisma decipiens (Ness ex Trin.) W.V. Br. (B 87)

Thrasyopsis repanda (Ness ex Trin.) Parodi (B 74)

Trachypogon spicatus (L.f.) Kuntze (B 81)

Trachypogon vestitus Anderson (B 14)

Tristachya leiostachya Ness. (B 11)

Poaceae sp1 (B 23)

Poaceae sp2 (B 44)

Poaceae sp3 (B 73)

Poaceae sp4 (B 65)

\section{Polygalaceae}

Polygala bryoides A.St-Hil. (B 66)

Polygala cuspidata DC. (B 70)

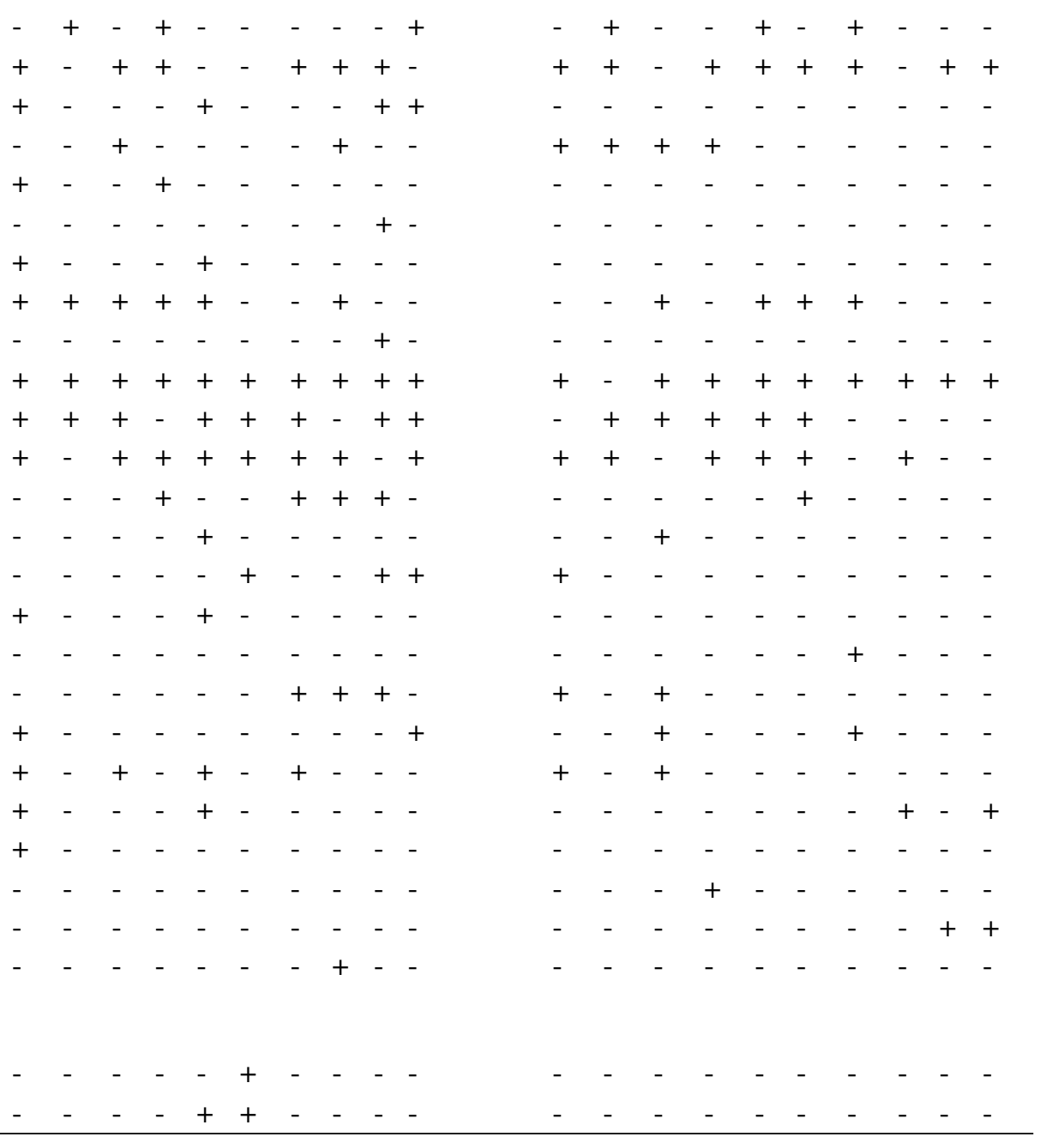




\begin{tabular}{|c|c|c|c|c|c|c|c|c|c|c|c|c|c|c|c|c|c|c|c|c|}
\hline \multirow[t]{2}{*}{ Family /Species } & \multicolumn{10}{|c|}{ Serra do Ouro Branco } & \multicolumn{10}{|c|}{ Serra do Ribeiro } \\
\hline & 1 & 2 & 3 & 4 & 5 & 6 & 7 & 8 & 9 & 10 & 1 & 2 & 3 & 4 & 5 & 6 & 7 & 8 & 9 & 10 \\
\hline Polygala filiformes A. St.-Hil. (B 51) & - & - & + & - & - & + & + & - & - & - & - & - & - & - & - & - & - & - & - & - \\
\hline Polygala longicaulis Humb.Borpl. \& Kunth (B 129) & + & + & + & + & + & + & + & + & - & - & + & + & - & + & + & + & - & - & - & - \\
\hline Polygala paludosa A.St. Hill. (B 60) & - & - & - & + & - & - & - & - & - & - & - & - & - & - & - & - & - & - & - & - \\
\hline Polygala paniculata L. (B 41) & - & - & + & + & - & - & + & + & + & + & + & + & - & + & + & + & + & - & - & + \\
\hline Polygala radlkoferi Chodat. (B 110) & - & - & - & - & - & - & - & - & - & - & - & - & - & - & - & - & - & - & + & - \\
\hline Polygala rhodoptera Mart. ex A.W.Benn. (B 48) & - & - & + & + & - & - & - & - & - & - & - & - & - & - & - & - & - & - & - & - \\
\hline Polygala sp1 (B 16) & + & + & - & - & - & - & + & - & - & - & - & - & - & - & - & - & - & - & - & - \\
\hline \multicolumn{21}{|l|}{ Rubiaceae } \\
\hline Galianthe angustifolia (Cham. \& Schltdl.) E.L. Cabral (B 19) & - & - & - & + & - & - & - & - & - & - & - & - & - & - & - & - & - & - & - & - \\
\hline Spermacoce verticillata L. (B 75) & - & - & - & - & - & - & + & - & - & - & + & - & - & - & - & - & - & - & - & - \\
\hline Spermacoce suaveolens (G. Mey.) Kuntze (B 68) & - & - & - & + & - & - & + & - & + & - & - & - & - & - & - & - & - & - & - & - \\
\hline Spermacoce neotenuis Govaerts (B 72) & - & - & - & - & - & - & + & - & - & - & + & - & - & - & - & - & - & - & - & - \\
\hline Declieuxia cordigera Mart. \& Zucc. (B 6) & + & + & - & + & + & + & + & - & - & - & - & - & - & - & - & - & - & - & - & - \\
\hline Psyllocarpus schwackei K. Schum. (B 38) & - & - & + & + & - & - & + & - & - & + & - & - & - & - & - & - & - & + & + & - \\
\hline \multicolumn{21}{|l|}{ Solanaceae } \\
\hline Schwenckia americana L. (B 95) & - & - & - & - & - & - & - & - & - & + & - & - & - & - & - & - & - & - & - & - \\
\hline \multicolumn{21}{|l|}{ Turneraceae } \\
\hline Turnera oblongifolia Cambess. (B 56) & - & - & - & + & - & - & - & - & - & - & - & - & - & - & - & - & - & - & - & - \\
\hline \multicolumn{21}{|l|}{ Verbenaceae } \\
\hline Lippia sericea Cham. (B 55) & - & - & - & + & - & - & - & - & - & - & - & - & - & - & - & - & - & - & - & - \\
\hline \multicolumn{21}{|l|}{ Xyridaceae } \\
\hline Xyris graminosa Pohl ex Mart. (B 113) & + & - & - & - & + & - & + & + & - & - & + & + & - & - & + & + & + & - & - & + \\
\hline Xyris trachyphylla Mart. (B 12) & - & - & + & + & - & - & + & - & - & - & - & - & - & - & - & - & - & - & - & - \\
\hline
\end{tabular}


variables, but, again, there was no significant variation in species richness with altitude: Asteraceae $\left(\chi^{2}=3.708 ; \mathrm{P}=0.054 ; \mathrm{n}=20\right)$, Cyperaceae $\left(\chi^{2}=1.081 ; \mathrm{P}=0.299 ; \mathrm{n}=20\right)$, Poaceae $\left(\chi^{2}=1.9702 ; \mathrm{P}=0.160 ; \mathrm{n}=20\right)$ and Polygalaceae $\left(\chi^{2}=0.554 ; \mathrm{P}=0.457 ; \mathrm{n}=20\right)$. Nevertheless, the number of species of families Poaceae $\left(\chi^{2}=3.741\right.$; $\mathrm{P}=0.05 ; \mathrm{n}=20)$, Asteraceae $\left(\chi^{2}=10.563 ; \mathrm{P}=\right.$ $0.001 ; \mathrm{n}=20)$ and Polygalaceae $\left(\chi^{2}=6.252 ; \mathrm{P}=\right.$ $0.01 ; \mathrm{n}=20$ ) was significantly higher in the SOB, whereas the number of species of Cyperaceae $\left(\chi^{2}\right.$ $=4.681 ; \mathrm{P}=0.03 ; \mathrm{n}=20$ ) was higher in the SR.

Forty-five species ( $44.5 \%$ of the total) were sampled in both serras, whose similarity was high $(\mathrm{J}=0.44)$, although the cluster and ordination analyses yielded two distinct groups (Fig. 3 and Fig. 4). The cluster analysis showed that contiguous points on the altitudinal gradient tend to be more similar, mainly in the SR, whose samples presented higher similarity values than those of the SOB.

Although the MDS analysis showed an organization similar to that of the UPGMA, it revealed different relationships between some points, i.e. points 1 and 2 of the SR and point 8 of the SOB; and the points 7, 9 and 10 of the SR (Fig. 4). The highest similarity value is between points 5 and 6 of the SR $(J=0.61)$, while points 9 and 10 of the SR grouped outside the set of the two serras (Fig. 3 and Fig. 4).

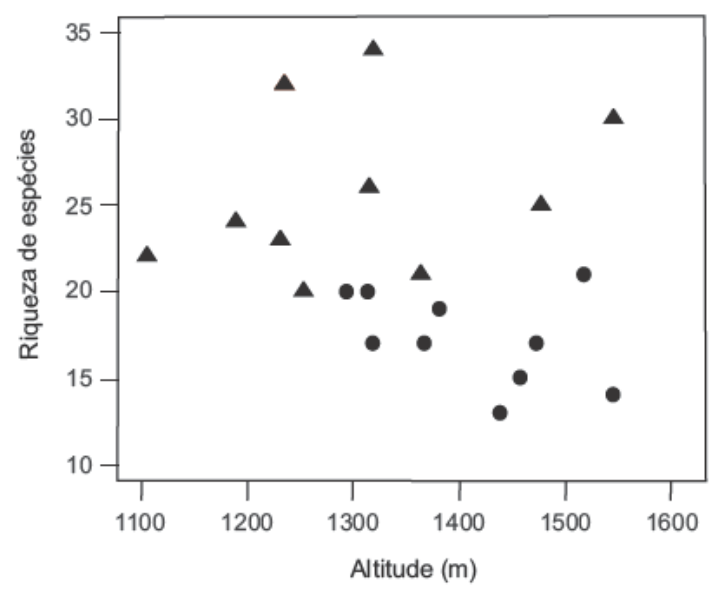

Figure 2 - Variation in herbaceous species richness according to altitude $\left(\chi^{2}=2.170 ; \mathrm{p}=0.141, \mathrm{n}=20\right)$.

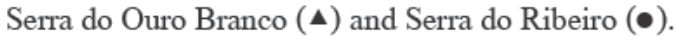

\section{Discussion}

The total herbaceous richness recorded in this study is similar to that reported in other floristic surveys in campos rupestres (Giulietti et al. 1987; Stannard 1995; Pirani et al. 2003; Zappi et al. 2003; Conceição \& Pirani 2005; Viana \& Lombardi 2007). However, these results are probably underrated because the sampled area was small and the field work was only carried out in one climatic season of the year, so that it does not take seasonal variations into account. The higher species richness found for families Poaceae, Asteraceae and Cyperaceae is also corroborated by previous work (Giulietti $e t$ al. 1987; Safford 1999; Filgueiras 2002).

The absence of exotic species at collection points shows that few disturbances affect the studied place, despite of the presence of cattle and the occurrence of frequent fires, especially in the $\mathrm{SOB}$, where populations of Melinis minutiflora $\mathrm{P}$. Beauv. and Hyparrhenia rufa (Nees) Stapf. grow along the highway that crosses it. The occurrence of fires increases the probability of intrusion of invasive African grasses as Melinis minutiflora, Urochloa decumbens Stapf. and Megathyrsus maximum Jacq. (Pivello 1999).

Although the geographical proximity and the similar orogeny of the two serras imply similar climatic conditions, geology and biogeographical history of the species, the SOB presented higher richness of herbaceous plants than the SR. A possible explanation is the effect of grazing and fires on the plant community structure of grassland vegetation (Howe 1994), since, in the SOB, the

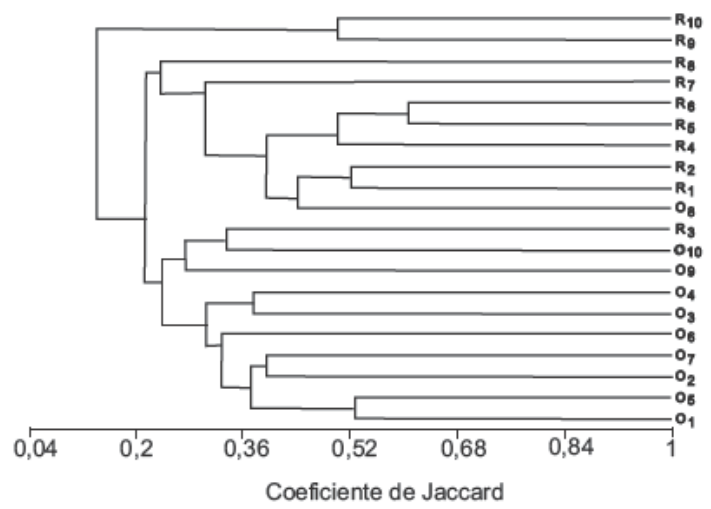

Figure 3 - Floristic similarity dendrogram based on Jaccard index among the 20 sampled points of both serras $\left(\mathrm{O}_{1-10}=\right.$ Serra de Ouro Branco, $\mathrm{R}_{1-10}=$ Serra do Ribeiro $)$. 


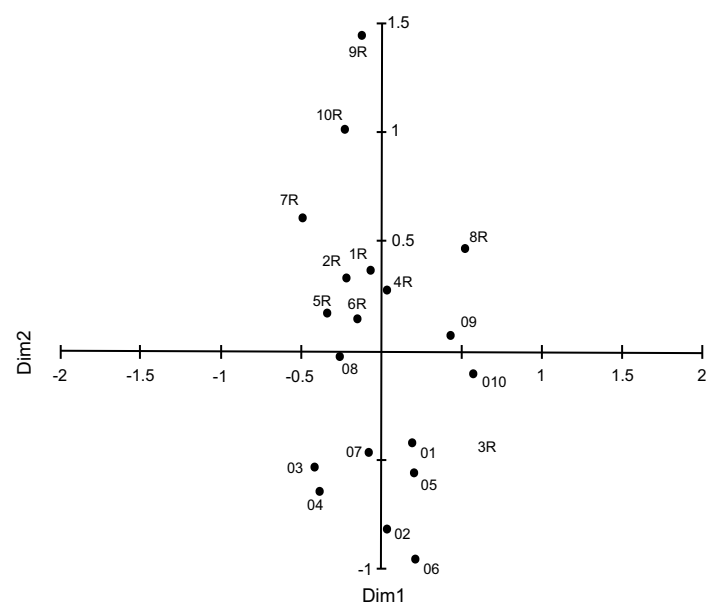

Figure 4-Multidimensional analysis of the similarity values between the 20 sampled points in the two serras $\left(\mathrm{O}_{1-10}=\right.$ Serra de Ouro Branco, $\mathrm{R}_{1-10}=$ Serra do Ribeiro $)$, resulting from 10,000 repetitions (Kruskal (1) stress $=$ $0.146)$.

presence of cattle and a more fires is frequently observed during the dry season.

Herbaceous species composition, mainly in natural grassland formations, has been found to present modifications related to the intensity and to the historical time of cattle grazing (Pucheta et al. 1998; Olff \& Ritchie 1998). When comparing samples of a same area impacted by large grazers in eastern Australia, McIntyre et al. 2003 verified that those with medium disturbance intensity presented higher plant richness as compared to samples with little or much disturbance, which they explained by a decrease in competition and an increase in regeneration.

Along the altitudinal gradient, local factors can be more important than regional ones to determine the occurrence of species (Pausas \& Austin 2001; Herzog et al. 2005). In this context, the facts that almost $30 \%$ of the total species occur in a single sampling point and that different species richness was found between samples at similar altitude suggest that the communities can be influenced by local factors or present a great natural variation in their species composition, with high $\hat{a}-$ diversity values (Lieberman et al. 1996). Again, one should keep in mind that the result interpretation is partial and restricted, due to the small sample size. In addition, the higher number of species of families Burmanniaceae, Cyperaceae, Eriocaulaceae and Gentianaceae in the Serra do Ribeiro is related to favorable local characteristics, as the presence of slopes with moist or soaked soils, a typical environment for given species of these families, as Burmannia bicolor Mart., Rhynchospora consanguinea Boeck. and Syngonanthus caulescens (Poir.) Ruhl.

According to Sano \& Almeida (1998), campos rupestres often shelter single species clusters, whose presence is conditioned, among others factors, by soil moisture. In the Espinhaço Range, seasonality is evident, with heavy cloud cover during the winter, which causes high moisture, sporadic rains and a lot of dew, so that some regions have a waterlogged soil all year round (Giulietti \& Pirani 1988).

The absence of pattern in species richness variation as altitude increases in both serras reflects the heterogeneity of the studied vegetation, which suggests the need of studies on the influence of local environmental and biological factors on the distribution of herbaceous plants, such as the availability of nutrients or water in the soil and competition or facilitation, respectively (MallenCooper \& Pickering 2008). The Espinhaço Range is a low altitude, very fragmented formation, which implies a small influence of macro-scale factors along the altitudinal gradient (Carneiro et al. 1995) as, for instance, climatic changes and the formation of different habitats (Whittaker et al. 2001).

Furthermore, the proximity between the sample points and the differences in elevation ranges and distances between them should also be considered to explain the absence of an altitudinal pattern. Nonetheless previous studies carried out on broader altitudinal ranges presented consistent variations in organism distribution, which resulted in a statistically significant relationship between species richness and altitude (Gottfried et al. 1999; Kessler 2000; Jones et al. 2003; Grytnes 2003; Bachman et al. 2004).

Since the serras presented a high number of species $(44.5 \%)$ in common, the formation of the two groups observed in the UPGMA and MDS analyses probably reflects the different occurrence of species at the sample points of each serra, which, in turn, have peculiarities similar to insular systems in the determination of species richness (Conceição $\&$ Pirani 2007). The higher similarity found between contiguous SR samples is probably due to the low species richness variation between them, since great part of the species of this serra grow in various sample points. 
Nevertheless, despite the small area sampled at each point, the marked difference between points 9 and 10, in the SR, may be related to their isolation in the landscape. In addition, the occurrence of species in specific places and the concentration of species in a single sampling point (Tab. 2) and the presence of different species richness between samples at similar altitude (Fig. 2) point out the importance of local factors in the species composition found, which contribute to the formation of mosaics in campos rupestres (Conceição \& Pirani 2005).

\section{Acknowledgements}

We thank researchers Dr. Rômulo Ribon (UFOP), Dr. Geraldo Wilson Fernandes (UFMG) and the two anonymous reviewers for their suggestions and criticisms of the manuscript; the Institute of Exact and Biological Sciences of the Federal University of Ouro Preto for their logistical support; and the Laboratory of Plant Systematics of the Department of Botany of the UFMG as well as Nadia S. Ávila (UMC) for identifying part of the collected materials.

\section{References}

Alkmim, F.F. 1987. Modelo Deposicional para a sequiência de metassedimentos da Serra de Ouro Branco, Quadrilátero Ferrífero, Minas Gerais. Anais do Simpósio sobre Sistemas Deposicionais no PréCambriano. Boletim da Sociedade Brasileira de Geologia, Núcleo MG 6: 47-68.

Angiosperm Phylogeny Group II: Bremer, B., Bremer, K., Chase, M.W., Reveal, J.L., Soltis, D.E., Soltis, P.S., Stevens, P.F. (coord.). 2003. An update of the Angiosperm Phylogeny Group classification for the orders \& families of flowering plants: APG II. Botanical Journal of the Linnean Society 141:399-436.

Araújo, G.M.; Barbosa A A.A.; Arantes A.A. \& Amaral A.F. 2002. Composição florística de veredas do município de Uberlândia, MG. Revista Brasileira de Botânica 25: 475-493.

Bachman, S.; Baker, W.J.; Brummit, N.; Dransfield, J. \& Moat, J. 2004. Elevational gradients, area and tropical island diversity: an example from the palms of New Guinea. Ecography 27: 299-310.

Beckage, B.; Osborne, B.; Gavin, D.G.; Pucko, C.; Siccama, T. \& Perkins, T. 2008. A rapid upward shift of a forest ecotone during 40 years of warming in the Green Mountains of Vermont. Proceedings National Academic of Science USA 105: 4197-4202.

Câmara, T.; Murta, R. 2007. Quadrilátero ferrífero: biodiversidade protegida. Gráfica Formato, Belo Horizonte. 200p.
Carneiro, M.A.A.; Ribeiro, S.P. \& Fernandes, G.W. 1995. Artrópodos de um gradiente altitudinal na Serra do Cipó, Minas Gerais, Brasil. Revista Brasileira de Entomologia 39: 597-604.

Conceição, A.A. \& Pirani, J.R. 2005. Delimitação de habitats em campos rupestres na Chapada Diamantina: substratos, composição florística e aspectos estruturais. Boletim de Botânica da Universidade de São Paulo 23: 85-111.

Conceição, A.A. \& Pirani, J.R. 2007. Diversidade em quatro áreas de campos rupestres na Chapada Diamantina, Bahia, Brasil: espécies distintas, mas riquezas similares. Rodriguésia 58: 193-206.

Colwell, R.K. \& Lewis, D.C. 2000. The mid-domain effect: geometric constraints

on the geography of species richness. Trends in Ecology and Evolution 15: 70-76.

Crawley, M.J. 2002. Statistical computing. An introduction to data analysis using S-plus. John Wiley \& Sons, New York. 761p.

Drummond, G.M.; Martins, C.S.; Machado, A.B.M.; Sebaio \& Antonini, Y. 2005. Biodiversidade em Minas Gerais: um atlas para sua conservação. $2^{\mathrm{a}}$. ed. Fundação Biodiversitas, Belo Horizonte. 222p.

Fernandes, G.W. \& Price P.W. 1988. Biogeographical gradients in galling species richness: tests of hypotheses. Oecologia 76: 161-167.

Filgueiras, T. 2002. Herbaceous plant communities. In: Oliveira P. S. \& Marquis R. J. The Cerrados of Brazil: ecology and natural history of a neotropical savanna. Columbia University Press, New York. Pp. 121-139.

Gentry, A.H. \& Dodson, C.H. 1987. Diversity and biogeography of neotropical vascular epiphytes. Annals of the Missouri Botanical Gardens 74: 205-233.

Giulietti, A.M.; Menezes, N.L.; Pirani, J.R.; Meguro, M. \& Wanderley, M.G.L. 1987. Flora da Serra do Cipó, Minas Gerais: caracterização e lista de espécies. Boletim de Botânica da Universidade de São Paulo. 9: 1-151.

Giulietti, A.M. \& Pirani, J.R. 1988. Patterns of Geographic Distribution of some Plant Species from the Espinhaço Range, Minas Gerais, Brazil. In: Proceedings of a Workshop on Neotropical Biodiversity Distribution Patterns. Academia Brasileira de Ciências, Rio de Janeiro. Pp. 39-69.

Givnish, T.J. 1999. On the causes of gradients in tropical trees diversity. Journal of Ecology 87: 193-210.

Gottfried, M.; Pauli, H.; Reiter, K. \& Grabherr, G. 1999. A fine-scaled predictive model for changes in species distribution patterns of high mountain plants induced by climate warming. Diversity and Distributions 5: 241-251.

Grytnes, J.A. 2003. Species-richness patterns of vascular plants along seven altitudinal transects in Norway. Ecography 26: 291-300. 
Herzog, S. K., Kessler, M. \& Bach, K. 2005. The elevational gradient in Andean bird species richness at the local scale: a foothill peak and a high-elevation plateau. Ecography 28: 209-222.

Hodkinson, I. D. 2005. Terrestrial insects along elevation gradients: species and community responses to altitude. Biological Reviews 80: 489-513.

Holmgren P.K, Holmgren, N.H. \& Barnett, L.C. 1990. Index Herbariorum. Part I: The herbaria of the world. New York Botanical Garden, New York. 120p.

Howe, H.F. 1994. Managing species diversity in tallgras prairie: assumptions and implications. Conservational Biology 8: 691-704.

Jones, J.I.; Li, W. \& Maberly, C. 2003. Area, altitude and aquatic plant diversity. Ecography 26: 411-420.

Kessler, M. 2000. Altitudinal zonation of Andean cryptogam communities. Journal of Biogeography 27: 275-282.

Krömer, T., Kessler, M., Gradstein, S.R. \& Acebey, A. 2005. Diversity patterns of vascular epiphytes along an elevational gradient in the Andes. Journal of Biogeography 32: 1799-1809.

Köppen, W. 1948. Climatologia; con un estudio de los climas de la tierra. Fondo de Cultura Economica, México. 478p.

Lieberman, D.; Lieberman, M.; Peralta, R. \& Hartshorn, G.S. 1996. Tropical forest structure and composition on a large-scale altitudinal gradient in Costa Rica. Journal of Ecology 84: 137-152.

Lomolino, M.V. 2001. Elevation gradients of speciesdensity: historical and prospective views. Global Ecology and Biogeography 10: 3-13.

Lomolino, M.V.; Riddle, B.R. \& Brown, J.H. 2006. Biogeography. 3rd ed. Sinauer Associates, Suderland. 845p.

Mallen-Cooper, J. \& Pickering, C.M. 2008. Linear declines in exotic and native plant species richness along an increasing altitudinal gradient in the Snowy Mountains, Australia. Austral Ecology 33: 684-690.

Martinelli, G. 2007. Mountain biodiversity in Brazil. Revista Brasileira de Botânica 30: 587-597.

McCoy, E.D. 1990. The distribution of insects along elevational gradients. Oikos 58: 313-322.

Mccune, B. \& Grace, J.B. 2002. Analysis of ecological communities. MjM Software Design, Oregon. 302p.

McIntyre, S.; Heard, K.M.; Martin, T.G. 2003. The relative importance of cattle grazing in subtropical grasslands: does it reduce or enhance plant biodiversity? Journal of Applied Ecology 40: 445-457.

Nor, M.D. 2001. Elevational diversity patterns small mammals on Mount Kinabalu, Sabah, Malaysia. Global Ecology \& Biogeography 10: 101-109.

Olff, H. \& Ritchie, M.E. 1998. Effects of herbivores on grassland plant diversity. Trends in Ecology and Evolution 13: 261-265.
Pausas, J.G. \& Austin, M.P. 2001. Patterns of plant species richness in relation to different environments: An appraisal. Journal of Vegetation Science 12: 153-166.

Pikälä, J. 2005. Plant species responses to cattle grazing in mesic semi-natural grassland. Agriculture, Ecosystems \& Environment 108: 109-117.

Pirani, J.R.; Mello-Silva, R.; Giulietti, A.M. 2003. Flora de Grão Mogol, Minas Gerais, Brasil. Boletim de Botânica da Universidade de São Paulo 21: 1-24.

Pivello, V.R.; Shida, C.N. \& Meirelles, S.T. 1999. Alien grasses in brazilian savannas: a threat to the biodiversity. Biodiversity and Conservation 8: 1281-1294.

Pucheta, E.; Cabido, M.; Díaz, S. \& Funes, G. 1998. Floristic composition, biomass, and aboveground net plant production in grazed and protected sites in a mountain grassland of central Argentina. Acta Oecologica 19: 97-105.

R Development Core Team. 2005. R: a language and environment for statistical computing. R Foundation for Statistical Computing, Viena. Disponível em <www.R-project.org>. Acesso em 10 Jul 2005.

Rahbek, C. 1997. The relationship among area, elevation, and regional species richness in Neotropical birds. American Naturalist 149: 875-902.

Rizzini, C.T. 1979. Tratado de fitogeografia do Brasil; Vol. 2. Edgard Blucher, EDUSP, São Paulo. 747p.

Romero, R. 2002. Diversidade dos campos rupestres de Goiás, sudoeste e sul de Minas Gerais. In: Biodiversidade, conservação e uso sustentável da flora do Brasil - Boletim da Sociedade Botânica do Brasil/UFRPE 81-86.

Rosenzweig, M.L. 1995. Species diversity in space and time. Cambridge University Press, Oxford. 436p.

Safford, H.F. 1999. Brazilian Páramos I. An introduction to the physical environment and vegetation of the campos de altitude. Journal of Biogeography 26: 693-712.

Sano, S.M. \& Almeida, S.P. (org.). 1998. Cerrado: ambiente e flora. EMBRAPA, Brasília, DF. 556p.

Shepherd, G.J. 1996. FITOPAC I - Manual do usuário. Universidade Estadual de Campinas, Campinas, 96p.

Stannard, B.L. 1995. Flora of the Pico das Almas, Chapada Diamantina, Brazil. Royal Botanical Gardens, Kew. 853p.

Terborgh, J. 1977. Bird species diversity on na Andean elevational gradient. Ecology 58: 1007-10019.

Tryon, R.M. 1989. Pteridophytes. In: Lieth, H. \& Werger, M.J.A. (eds.). Tropical rain forest ecosystems. Biogeographical and ecological studies. Ecosystems of the world V, 14b. Elsevier, Amsterdan. Pp. 327-338.

Viana, P.L. \& Lombardi, J.A. 2007. Florística e caracterização dos campos rupestres sobre canga na 
Serra da Calçada, Minas Gerais, Brasil. Rodriguésia 58: 159-177.

Whittaker R. J.; Willis K. J. \& Field R. 2001. Scale and species richness: towards a general, hierarchical theory of species diversity. Journal of Biogeography 28: 453-70.
Zappi, D.C.; Lucas, E.; Stannard, B.; Lughadha, E.; Pirani, J.R.; Queiroz, L.P.; Atkins, S.; Hind, D.J.N.; Giulietti, A.M.; Harley, R. \& Carvalho, AM. 2003. Lista das plantas vasculares de Catolés, Chapada Diamantina, Bahia, Brasil. Boletim de Botânica da Universidade de São Paulo 21: 345-398. 